Article

\title{
Vegetation Structure and Carbon Stocks of Two Protected Areas within the South-Sudanian Savannas of Burkina Faso
}

\author{
Mohammad Qasim ${ }^{1}$, Stefan Porembski ${ }^{2}$, Dietmar Sattler ${ }^{3}$, Katharina Stein ${ }^{2,4}$, \\ Adjima Thiombiano ${ }^{5}$ and André Lindner ${ }^{6, *}$ \\ 1 Institute of International Forestry and Forest Products, Technische Universität Dresden, Pienner Strasse 7, \\ Tharandt 01737, Germany; mohammadqasimkhan@yahoo.com \\ 2 Department of Botany, Institute of Biological Sciences, University of Rostock, Wismarsche Str. 8, \\ Rostock 18051, Germany; stefan.porembski@uni-rostock.de (S.P.); katharina.stein@uni-wuerzburg.de (K.S.) \\ 3 Department of Physical Geography and Geo-Ecology, Institute for Geography, University of Leipzig, \\ Johannisallee 19a, Leipzig 04103, Germany; sattler@uni-leipzig.de \\ 4 Department of Animal Ecology and Tropical Biology, University of Wuerzburg, Josef-Martin-Weg 52, \\ Wuerzburg 97074, Germany \\ 5 Laboratoire de Biologie et Ecologie Végétales, Université de Ouagadougou, UFR/SVT, \\ Ouagadougou 03 BP 7021, Burkina Faso; adjima_thiombiano@yahoo.fr \\ 6 Centre for International Postgraduate Studies of Environmental Management-CIPSEM, \\ Technische Universität Dresden, Zellescher Weg 41c, Dresden 01207, Germany \\ * Correspondence: andre.lindner@tu-dresden.de; Tel.: +49-351-463-11914
}

Academic Editor: Yu-Pin Lin Received: 14 August 2016; Accepted: 21 September 2016; Published: 29 September 2016

Abstract: Savannas and adjacent vegetation types like gallery forests are highly valuable ecosystems contributing to several ecosystem services including carbon budgeting. Financial mechanisms such as REDD+ (Reduced Emissions from Deforestation and Forest Degradation) can provide an opportunity for developing countries to alleviate poverty through conservation of its forestry resources. However, for availing such opportunities carbon stock assessments are essential. Therefore, a research study for this purpose was conducted at two protected areas (Nazinga Game Ranch and Bontioli Nature Reserve) in Burkina Faso. Similarly, analysis of various vegetation parameters was also conducted to understand the overall vegetation structure of these two protected areas. For estimating above ground biomass, existing allometric equations for dry tropical woody vegetation types were used. Compositional structure was described by applying tree species and family importance indices. The results show that both sites collectively contain a mean carbon stock of $3.41 \pm 4.98 \mathrm{Mg} \cdot \mathrm{C} \cdot \mathrm{ha}^{-1}$. Among different savanna vegetation types, gallery forests recorded the highest mean carbon stock of $9.38 \pm 6.90 \mathrm{Mg} \cdot \mathrm{C} \cdot \mathrm{ha}^{-1}$. This study was an attempt at addressing the knowledge gap particularly on carbon stocks of protected savannas-it can serve as a baseline for carbon stocks for future initiatives such as REDD+ within these areas.

Keywords: aboveground biomass; degradation; gallery forest; West Africa; woody vegetation

\section{Introduction}

The population of Burkina Faso was recorded as 15.7 million in 2009. It is spread over an area of $274,000 \mathrm{~km}^{2}$ and almost $80 \%$ of the population lives in rural areas and depends on agriculture as their main source of mainstay [1]. The population depends heavily on fuelwood as their main source of energy [2]. Moreover, livestock production and increases in population have put undue pressures on plant resources [3]. As a consequence, the vegetation structure and composition of the savanna habitats have been severely affected [4]. This degradation is further leading to challenges such as 
food shortages, water scarcities, income losses, resource conflicts, and environmental deterioration [5]. Poverty and increasing need for food have resulted in agricultural expansions [6].

Burkina Faso can be divided into two main agro-ecological zones (i.e., Sahelian savanna and Sudanian savanna), categorized on the basis of isohyets and length of dry season [7]. The Sahelian savanna has a dry season of seven to nine months annually with annual rainfall of $600 \mathrm{~mm}$. The Sudanian savanna has a dry season of four to seven months annually with annual rainfall of 750-1200 mm [8]. The Sahelian savanna can further be categorized into Northern Sahelian savanna (with annual rainfall of $600 \mathrm{~mm}$ and eight to nine months of dry season) and Southern Sahelian savanna (with annual rainfall of 600-750 mm and seven to eight months of dry season) [9]. Similarly, the Sudanian savanna can further be categorized into Northern Sudanian savanna (with annual rainfall of 750-1000 mm and six to seven months of dry season) and Southern Sudanian savanna (with annual rainfall of 1000-1200 $\mathrm{mm}$ and four to six months of dry season) [9].

Burkina Faso has a forest area of 19.6\%, with additional 17.5\% categorized as "other woodlands" [10]. The increasing pressure on forestry resources has resulted in a significant annual deforestation rate of 1.0\% for the period 2010-2015 [10]. In addition, climate change constitutes a serious challenge which is undermining efforts towards sustainable development. Carbon sequestration can therefore serve as an essential strategy for the mitigation of climate change [11]. Forest resources, on the other hand, can be helpful in addressing climate vulnerabilities, such as food insecurity [12]. Reduced Emissions from Deforestation and Forest Degradation (REDD+) is a financial scheme focused upon reducing carbon emissions, which involves reducing emissions from deforestation and forest degradation, that is aimed towards the conservation and enhancement of forest carbon stocks, and a sustainable forest management including ecological and social targets [13]. Hence, REDD+ not only just provides developing countries the opportunity to tackle climate change by alleviating poverty but also helps by conserving their forest resources [14]. Moreover, it has also been identified as one of the economically most feasible mitigation options in tackling climate change [15]. The most important issue for REDD+ initiatives, however, is the estimation and the monitoring of the carbon stocks, and their success therefore largely depends on the availability of scientific information on forest carbon stocks [16]. Unfortunately, sufficient work on the quantification of carbon stocks in savannas does not exist [17]. Additionally, savannas have also been a major uncertainty in the carbon accounting of Africa [18].

The information on the composition and structural characteristics of the tree species in savannas are often lacking. Trees are considered an important component of vegetation and must be persistently monitored so that the forest successional processes can be managed for maintaining habitat diversity [19]. Such quantitative information can be helpful in developing appropriate conservation guidelines for the savannas. The composition and structural characteristics of the vegetation also help in understanding the magnitude of anthropogenic pressures on ecosystems. In Burkina Faso, like other countries in the world, protected areas were also established to safeguard the unique biodiversity for respective areas. Moreover, the protected areas also play an essential role in carbon sequestration [20]. Burkina Faso has $14 \%$ of its total land area categorized as protected areas and has future plans to increase the number to $30 \%$ [9].

The study therefore focused on assessing general composition and vegetation structure as well as the carbon stocks $\left(\mathrm{Mg} \cdot \mathrm{C} \cdot \mathrm{ha}^{-1}\right)$ in aboveground biomass $(A G B)_{\mathrm{dry}}$ of trees of typical vegetation types in two protected areas of Burkina Faso: Nazinga Game Ranch and Bontioli Nature Reserve. The main objective of this study is to provide a benchmark for future studies and baselines for future possible initiatives (e.g., REDD+), if initiated for these areas.

\section{Materials and Methods}

\subsection{Study Area}

Nazinga Game Ranch was created in 1979 (Figure 1) and is spread over an area of 97,536 ha at an average altitude of $280 \mathrm{~m}$ above sea level (asl) [21]. According to Burkina Faso's legislation, 
it has been classified as a protected area, listed as a "Wildlife Reserve" and it is very well known as a tourist destination [22]. There is a single dry season running from October to May and a single rainy season from June to September. It has a mean annual rainfall of $900 \mathrm{~mm}$ [23]. The average annual temperature is $27.1^{\circ} \mathrm{C}$. The Nazinga Game Ranch is traversed by Sessile River and its two tributaries (i.e., Dawevele and Nazinga Rivers); the rivers have characteristic seasonal flows. The vegetation has the characteristics of Southern Sudanian savanna. Typical species of the area include; shea tree (Vitellaria paradoxa C.F. Gaertn.), kodayoru tree (Terminalia laxiflora Engl. \& Diels), female gardenia (Gardenia erubescens Stapf \& Hutch.), lingahi tree (Afzelia africana Sm.), and African birch (Anogeissus leiocarpa (DC.) Guill. \& Perr.), among others [24].

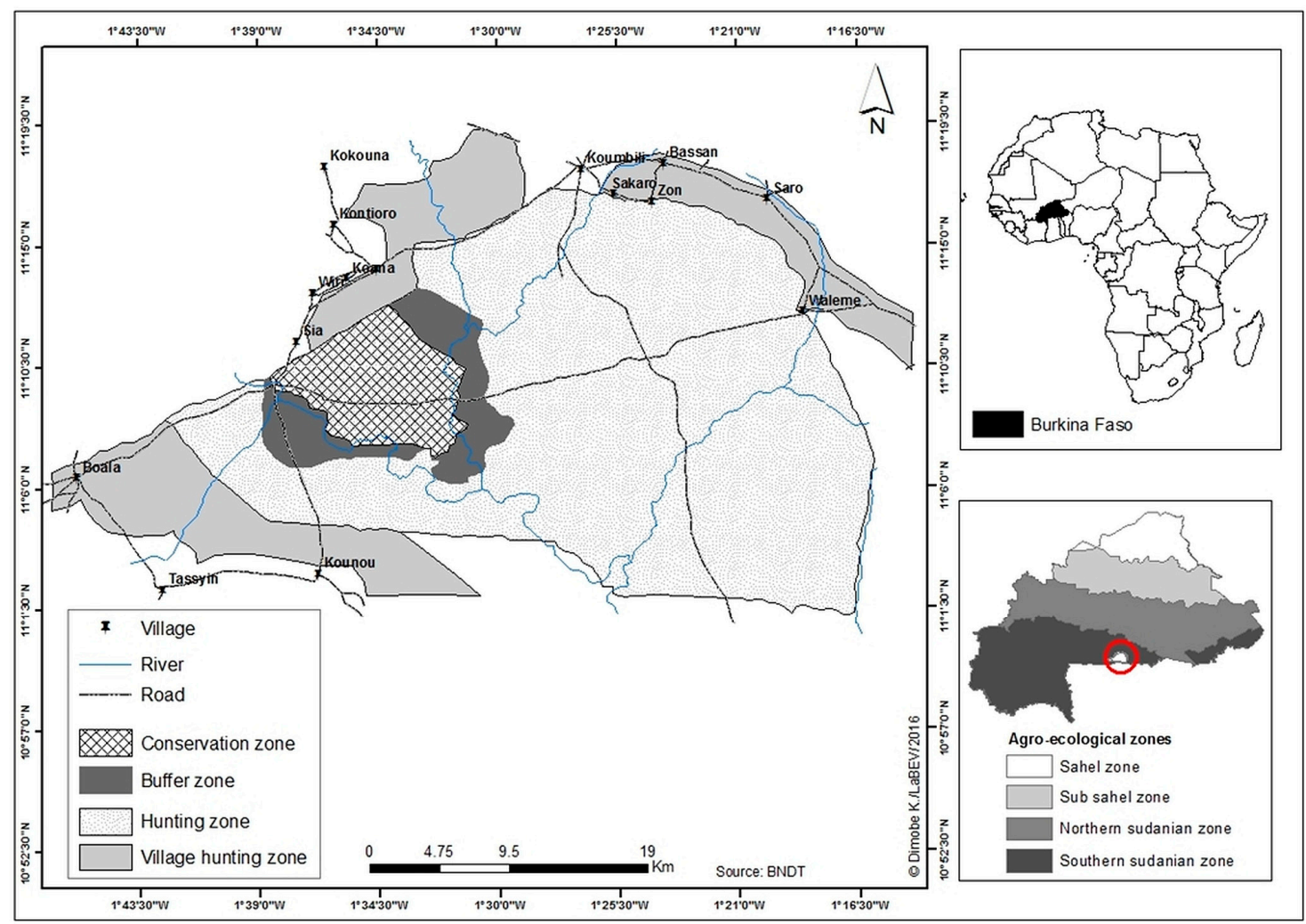

Figure 1. Nazinga Game Ranch, Burkina Faso.

For better management purposes, the Nazinga Game Ranch has been divided into four zones: (i) conservation zone; (ii) buffer zone; (iii) commercial hunting zone; and (iv) village hunting zone. The conservation zone consists of $9 \%$ and the buffer zone consists of $5 \%$ of the total area. The commercial hunting zone and the village hunting zone comprise the remaining $86 \%$ of the total area [21]. A few settlements are also located in the commercial hunting zone and village hunting zone. The area has once known to be one of the least populated areas in Burkina Faso, but has been subjected to increasing migrations after the Sahelian drought in the 1970s [23]. Agriculture is the mainstay for the local people and the major agricultural crops are corn (Zea mays L.), sorghum (Sorghum bicolor (L.) Moench), pearl millet (Pennisetum glaucum (L.) R. Br.), and peanut (Arachis hypogaea L.).

Bontioli Nature Reserve is also called "Forêt Classée de Bontioli" and is located in the Sudanian zone of southwestern Burkina Faso in the province of Bougouriba (Figure 2). It is a Category IV protected area, managed mainly for conservation through active management, according to International Union for Conservation of Nature (IUCN) Protected Areas Categories. It consists of the Total Reserve and the Partial Reserve. These areas were established by the territorial government during the colonial period based on two ministerial orders; (i) Order n ${ }^{\circ} 3147$ /SE/EF of 23 March 1957, which was related to the demarcation of the area $(29,500$ ha) and the establishment of the Partial Reserve (ii) Order 
3417/SE/EF of 29 March 1957, which was related to the demarcation of the area and classification of the Total Reserve (12,700 ha). The research study was confined to the Total Reserve only, as the Partial Reserve of Bontioli does not have consistent savanna cover due to being subjected to high pressure from human activities [25].

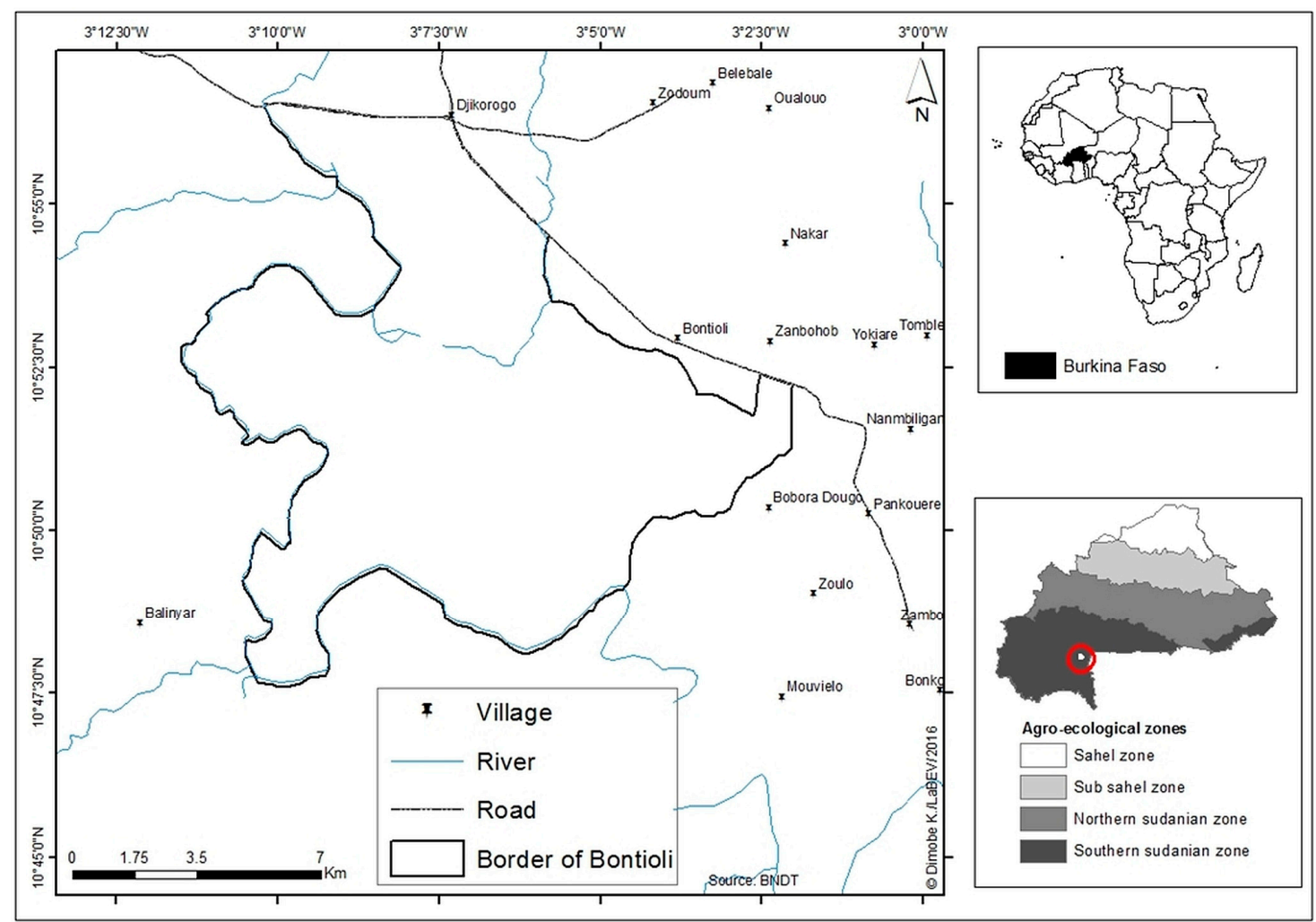

Figure 2. Bontioli Nature Reserve, Burkina Faso.

The vegetation of the Bontioli Nature Reserve also has the characteristics of the Southern Sudanian savanna. The rainfall varies between 900 and $1000 \mathrm{~mm}$ per year [25]. The rainy season ranges from May to October and the dry season spans from November to April [26]. The mean temperature has been recorded as $27.1^{\circ} \mathrm{C}$ for the period of 2004-2006. The main river is the Bougouriba, which is pivotal for the hydrographical network within the Bontioli Nature Reserve [25]. The highest altitude for the Bontioli Nature Reserve has been recorded as $350 \mathrm{~m}$ asl and the lowest altitude as $250 \mathrm{~m}$ asl. The tree species include wild syringe (Burkea africana Hook.), barwood (Pterocarpus erinaceus Poir.), ordeal tree (Crossopteryx febrifuga (Afzel. ex G. Don) Benth.), and cangara tree (Combretum glutinosum Perr. ex DC).

\subsection{Sampling Design}

Due to the heterogeneous and overlapping landscape matrix a stratified sampling design was adopted for this study. The vegetation at both sites is classified as Southern Sudanian savanna [27]. The vegetation was further segregated into different types according to their physiognomy; (i) woodland savanna; (ii) tree savanna; (iii) shrub savanna; and (iv) gallery forest [28]. The tree and shrub savannas were categorized according to the Yangambi classification in 1956 [29]. Gallery forests were categorized as the narrow patches found along the fringes of semi-permanent water courses [30]. Woodland savannas were categorized on the basis of their close canopies and discontinuous grasses [31]. Twenty plots were established at either site, with five plots each per vegetation type. The plots were square-shaped and had a size of $20 \mathrm{~m} \times 20 \mathrm{~m}$, as suggested by [32]. 


\subsection{Data Collection and Analysis}

\subsection{1. $A G B_{\mathrm{dry}}$ and Carbon Stock Estimation}

The diameter at breast height $(D B H)$ over bark for each tree $\geq 5 \mathrm{~cm}$ in every plot was measured with the help of the diameter tape at $1.3 \mathrm{~m}$ above ground level. In case of multi-stemmed trees, all stems with $D B H$ above $5 \mathrm{~cm}$ were measured and the following formula was used for calculation of the respective total $D B H[33]$;

$$
D B H_{\text {total }}(\mathrm{cm})=2 \times \sqrt{ }\left(D B H_{1}\right)^{2} / 2+\ldots+\left(D B H_{n}\right)^{2} / 2
$$

The heights of the trees were estimated using Blume Leiss Hypsometer. The heights of trees less than two meters were measured with the help of a measuring tape. For multi-stemmed trees such as Mitragyna inermis (Willd.) Kuntze, the tip of the tallest stem was measured.

For tree $A G B_{d r y}$ estimation, the allometric equation suggested by [34] for dry forest stands was used, which is valid for $D B H$ within the range of $5-156 \mathrm{~cm}$;

$$
A G B_{d r y}(\mathrm{~kg})=0.112 \times\left(\rho D B H^{2} H\right)^{0.916}
$$

where $H=$ height $(\mathrm{m})$ and $\rho=$ Wood Density $\left(\mathrm{g} \cdot \mathrm{cm}^{-3}\right)$.

The published wood densities were used for the $A G B_{\text {dry }}$ estimation (Table A1). The wood densities at species or generic level were used subject to their availability [35]. The $A G B_{\text {dry }}$ per plot was scaled up to $\mathrm{Mg} \cdot \mathrm{ha}^{-1}$. The $A G B_{\mathrm{dry}}$ (in $\mathrm{Mg} \cdot \mathrm{ha}^{-1}$ ) was converted to carbon stocks by multiplying with a carbon conversion factor of 0.5 [36].

\subsubsection{Quadratic Mean Diameter and Density}

The quadratic mean diameter for every plot was calculated as $\sqrt{ }\left(\sum d_{i}^{2}\right) / n\left(d_{i}\right.$ is $D B H$ in $\mathrm{cm}$ for every tree and $n$ refers to the total number of trees) [37]. The quadratic mean diameter is referred to as mean $D B H$ throughout the document hereafter. The density was the total number of trees per plot per ha.

2.3.3. Basal Area (BA), Importance Value Index (IVI), and Family Importance Value (FIV)

The BA for each sampled tree was calculated as the following;

$$
B A=(D B H / 2)^{2} \times \pi \times \text { expansion factor for ha }
$$

IVIs were calculated from the species relative frequency $(R f)$, relative density $(R D e)$, and relative dominance $(R D o)$ [38];

$$
\begin{gathered}
R f(\%)=\frac{\text { Number of plots present with the species }}{\text { Total number of plots }} \times 100 \\
R D e(\%)=\frac{\text { Number of individuals of a species }}{\text { Total number of individuals }} \times 100 \\
R D o(\%)=\frac{\text { Total BA of a species }}{\text { Total BA for all species }} \times 100
\end{gathered}
$$

IVI for each species was calculated as the sum of $R f, R D e$, and $R D o$. The FIVs were calculated from relative diversity $(R D i)$, relative density $(R D e)$, and relative dominance $(R D o)$ according to [39];

$$
\begin{aligned}
& R D i(\%)=\frac{\text { Number of species in family }}{\text { Total number of species }} \times 100 \\
& R D e(\%)=\frac{\text { Number of trees in family }}{\text { Total number of trees }} \times 100
\end{aligned}
$$




$$
R D o(\%)=\frac{\text { BA of family }}{\text { Total BA }} \times 100
$$

FIV for each family was eventually calculated as the sum of $R D i, R D e$, and $R D o$.

\subsection{Statistical Analysis}

To assess the normal distribution of different variables, the Shapiro-Wilk-Test was used. The means \pm Standard Deviations $(S D)$ for averages of different variables per plot were calculated. As some data was not normally distributed, Wilcoxon Rank Sum Test was used for probing the statistical differences between two variables and Kruskal Wallis Rank Sum Test was used for more than two variables. The post-hoc analysis for significant differences in means was done using Tukey's test. A significance level of 0.05 was used for all statistical tests. The statistical analysis was performed and graphs were produced using the version 3.1.0 of R (R Foundation for Statistical Computing, Vienna, Austria) [40].

\section{Results}

\subsection{DBH and Height}

No significant difference was recorded between mean DBHs of two sites $(p>0.05)$. The mean $D B H$, however, differed significantly amongst the vegetation types for both sites collectively $(p<0.05)$. The mean $D B H$ of gallery forests showed significant variation from the other vegetation types for both sites collectively $(p<0.05$; Table 1$)$. The gallery forests recorded the highest mean DBH of $48.80 \pm 16.45 \mathrm{~cm}$ for both sites collectively. The $D B H$ classes for both sites showed a reverse J-shape. For Nazinga Game Ranch, the highest number of the trees was recorded in the $D B H$ class of $5 \mathrm{~cm}$, forming $43.07 \%$ of the total (Figure 3). Together, $5 \mathrm{~cm}$ and $10 \mathrm{~cm} \mathrm{DBH}$ classes formed $74.61 \%$ of the total stems for Nazinga Game Ranch. Similarly, for Bontioli Nature Reserve, $5 \mathrm{~cm}$ DBH classes formed 36.17\% of the total and together $5 \mathrm{~cm}$ and $10 \mathrm{~cm}$ combined to form $68.08 \%$ of the total sampled stems (Figure 3).

Table 1. Structural characteristics of the four vegetation types at the study sites of Nazinga Game Ranch and Bontioli Nature Reserve.

\begin{tabular}{|c|c|c|c|c|c|}
\hline \multirow{2}{*}{ Sites } & \multicolumn{4}{|c|}{ Vegetation Types } & \multirow[t]{2}{*}{ Total } \\
\hline & Woodland Savanna & Tree Savanna & Gallery Forest & Shrub Savanna & \\
\hline \multicolumn{6}{|c|}{ Nazinga Game Ranch } \\
\hline Mean $D B H(\mathrm{~cm})$ & $22.12 \pm 6.47$ & $12.02 \pm 2.25$ & $45.67 \pm 10.51$ & $9.36 \pm 1.09$ & $26.49 \pm 15.44$ \\
\hline Mean tree height (m) & $9.38 \pm 2.55$ & $5.26 \pm 0.50$ & $9.41 \pm 1.00$ & $4.37 \pm 1.27$ & $7.11 \pm 2.75$ \\
\hline Mean Density (trees $\cdot \mathrm{ha}^{-1}$ ) & $160 \pm 8.31$ & $80.5 \pm 7.52$ & $73.75 \pm 8.98$ & $11.25 \pm 1.62$ & $325 \pm 60.99$ \\
\hline Mean BA $\left(\mathrm{m}^{2} \cdot \mathrm{ha}^{-1}\right)$ & $0.96 \pm 0.49$ & $0.28 \pm 0.10$ & $4.09 \pm 1.70$ & $0.17 \pm 0.04$ & $1.37 \pm 1.84$ \\
\hline Mean Carbon $\left(\mathrm{Mg} \cdot \mathrm{C} \cdot \mathrm{ha}^{-1}\right)$ & $3.01 \pm 1.82$ & $0.50 \pm 0.25$ & $9.32 \pm 3.71$ & $0.24 \pm 0.09$ & $3.27 \pm 4.22$ \\
\hline Mean $A G B_{\text {dry }}\left(\mathrm{Mg} \cdot \mathrm{ha}^{-1}\right)$ & $6.03 \pm 3.64$ & $1.00 \pm 0.50$ & $18.64 \pm 7.42$ & $0.49 \pm 0.19$ & $6.54 \pm 8.41$ \\
\hline \multicolumn{6}{|c|}{ Bontioli Nature Reserve } \\
\hline Mean $D B H(\mathrm{~cm})$ & $19.72 \pm 4.24$ & $12.94 \pm 2.90$ & $49.61 \pm 23.00$ & $13.66 \pm 6.98$ & $30.15 \pm 18.19$ \\
\hline Mean tree height (m) & $9.17 \pm 1.45$ & $6.49 \pm 0.40$ & $9.52 \pm 1.81$ & $4.62 \pm 1.99$ & $7.45 \pm 2.50$ \\
\hline Mean Density (trees $\cdot \mathrm{ha}^{-1}$ ) & $145 \pm 13.53$ & $130 \pm 10.98$ & $61.25 \pm 8.98$ & $16.25 \pm 3.25$ & $352.5 \pm 60.21$ \\
\hline Mean BA $\left(\mathrm{m}^{2} \cdot \mathrm{ha}^{-1}\right)$ & $1.05 \pm 0.41$ & $0.45 \pm 0.27$ & $5.25 \pm 5.26$ & $0.36 \pm 0.41$ & $1.78 \pm 2.33$ \\
\hline Mean Carbon $\left(\mathrm{Mg} \cdot \mathrm{C} \cdot \mathrm{ha}^{-1}\right)$ & $3.13 \pm 1.14$ & $0.98 \pm 0.66$ & $9.45 \pm 9.66$ & $0.67 \pm 0.76$ & $3.56 \pm 3.41$ \\
\hline Mean $A G B_{\text {dry }}\left(\mathrm{Mg} \cdot \mathrm{ha}^{-1}\right)$ & $5.92 \pm 2.74$ & $1.42 \pm 0.42$ & $18.91 \pm 19.33$ & $1.24 \pm 1.61$ & $6.87 \pm 11.63$ \\
\hline \multicolumn{6}{|c|}{ Both Sites Collectively * } \\
\hline Mean $D B H(\mathrm{~cm})$ & $22.66 \pm 5.43 a$ & $13.73 \pm 3.59 \mathrm{a}$ & $48.80 \pm 16.45 b$ & $11.74 \pm 4.95 \mathrm{a}$ & $28.38 \pm 16.70$ \\
\hline Mean tree height (m) & $9.28 \pm 1.96 a$ & $5.88 \pm 0.77 \mathrm{~b}$ & $9.47 \pm 1.38 \mathrm{a}$ & $4.50 \pm 1.58 b$ & $7.28 \pm 2.60$ \\
\hline Mean Density (trees $\cdot \mathrm{ha}^{-1}$ ) & $305 \pm 10.70 \mathrm{ac}$ & $210 \pm 10.32 a$ & $135 \pm 8.57 \mathrm{ad}$ & $27.5 \pm 2.48 b$ & $677.5 \pm 117.40$ \\
\hline Mean BA $\left(\mathrm{m}^{2} \cdot \mathrm{ha}^{-1}\right)$ & $1.00 \pm 0.43 a$ & $0.37 \pm 0.21 \mathrm{a}$ & $4.67 \pm 3.73 b$ & $0.27 \pm 0.29 a$ & $1.58 \pm 2.08$ \\
\hline Mean Carbon $\left(\mathrm{Mg} \cdot \mathrm{C} \cdot \mathrm{ha}^{-1}\right)$ & $3.07 \pm 1.43 a$ & $0.74 \pm 0.53 a$ & $9.38 \pm 6.90 b$ & $0.45 \pm 0.56 a$ & $3.41 \pm 4.98$ \\
\hline Mean $A G B_{\text {dry }}\left(\mathrm{Mg} \cdot \mathrm{ha}^{-1}\right)$ & $5.97 \pm 3.04 \mathrm{a}$ & $1.21 \pm 0.49 \mathrm{a}$ & $18.77 \pm 13.80 \mathrm{~b}$ & $0.86 \pm 1.15 \mathrm{a}$ & $6.70 \pm 10.02$ \\
\hline
\end{tabular}

*Within rows (excluding "Total" column) of "Both Sites Collectively", means ( \pm SD) not sharing a common lower case, differ significantly $(p<0.05)$ based on Tukey's test for comparison of means. DBH, diameter at breast height. 
Similarly, no significant difference was recorded between mean heights of the two sites $(p>0.05)$. Significant difference was recorded amongst the vegetation types for both sites collectively $(p<0.05$; Table 1). The mean heights of gallery forests and woodland savannas differed significantly from the tree and shrub savannas ( $p<0.05$; Table 1$)$. The largest value of $9.47 \pm 1.38 \mathrm{~m}$ for mean height was recorded for the gallery forests for both sites collectively (Table 1).

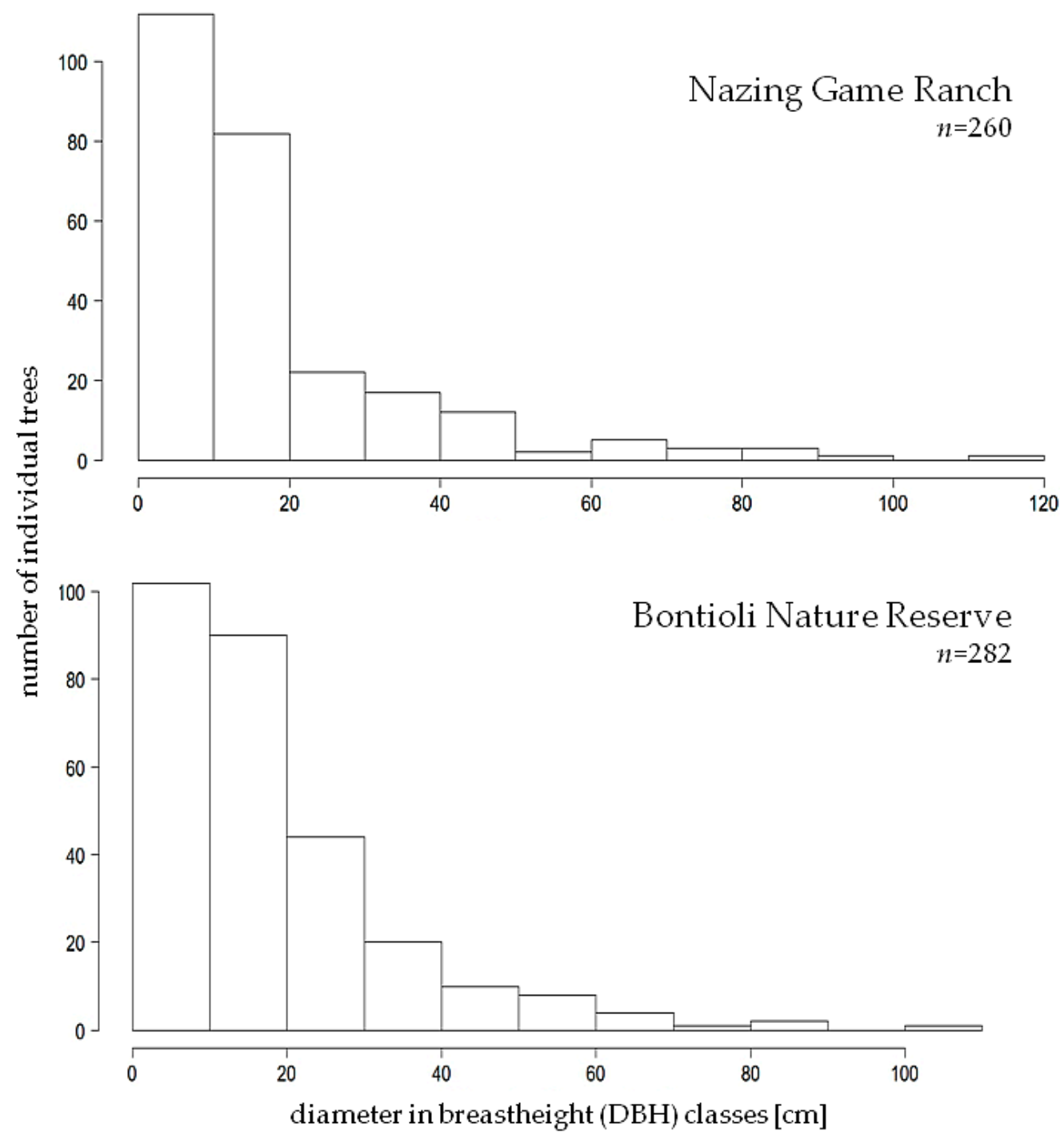

Figure 3. Distribution of individual trees in according $D B H$ classes for both research sites, Nazinga Game Ranch (upper part) and Bontioli Nature Reserve (lower part).

\subsection{Density and $B A$}

No significant difference was recorded between mean densities of two sites $(p>0.05)$. Variation in mean densities of all vegetation types for both sites collectively was, however, recorded $(p<0.05)$. The highest mean density of $305 \pm 10.70$ trees $\cdot \mathrm{ha}^{-1}$ was recorded for the woodland savannas for both sites collectively (Table 1). Shrub savannas with mean density of $27.5 \pm 2.48$ trees $^{-h^{-1}}$ were $^{-1}$ significantly different from other vegetation types $(p<0.05$; Table 1$)$. The mean densities of woodland savannas and gallery forests were also significantly different from each other $(p<0.05$; Table 1$)$.

There was no significant difference between the mean BA for the two sites either $(p>0.05)$. Significant difference was recorded between vegetation types for both sites collectively $(p<0.05$; Table 1). The mean BA for gallery forests was significantly different from other vegetation types for 
both sites collectively ( $p<0.05$; Table 1$)$. The highest mean BA of $4.67 \pm 3.73 \mathrm{~m}^{2} \cdot \mathrm{ha}^{-1}$ was recorded for the gallery forests for both sites collectively (Table 1).

\section{3. $A G B_{d r y}$}

No significant difference was recorded for the mean $A G B_{\mathrm{dry}}$, for both sites collectively $(p>0.05)$. Significant difference in mean $A G B_{\text {dry }}$ was recorded for the vegetation types for both sites collectively ( $p<0.05$; Table 1$)$. The mean $A G B_{\text {dry }}$ for gallery forests was significantly different from other vegetation types collectively for both sites ( $p<0.05$; Table 1$)$. The overall mean $A G B_{\mathrm{dry}}$ for both sites collectively was $6.70 \pm 10.02 \mathrm{Mg} \cdot \mathrm{ha}^{-1}$ (Table 1). Amongst vegetation types for both sites collectively, the highest mean $A G B_{\text {dry }}$ was recorded for gallery forests, $18.77 \pm 13.80 \mathrm{Mg} \cdot$ ha $^{-1}$ (Table 1 ).

\subsection{Carbon Stocks}

There was no significant difference between the mean carbon stocks of the two sites $(p>0.05)$. Significant difference, however, was recorded among the vegetation types collectively for both sites $(p<0.05$; Table 1). The mean carbon stock for gallery forests was significantly different from other vegetation types for both sites collectively $(p<0.05$; Table 1$)$. The overall mean carbon stock for both sites collectively was recorded as $3.41 \pm 4.98 \mathrm{Mg} \cdot \mathrm{C} \cdot \mathrm{ha}^{-1}$ (Table 1 ). Gallery forests also showed the highest mean carbon stock, $9.38 \pm 6.90 \mathrm{Mg} \cdot \mathrm{C} \cdot \mathrm{ha}^{-1}$ (Table 1 ).

\subsection{IVI, FIV, and Relative Abundance of Trees}

Amongst the tree species for both sites collectively, Anogeissus leiocarpa was dominant with $28.04 \%$ (Table A1). Mitragyna inermis and Vitellaria paradoxa followed with $12.91 \%$ and $12.36 \%$, respectively (Table A1). At Nazinga Game Ranch, the highest IVI of 115.56 was recorded for Anogeissus leiocarpa (Table A2). Mitragyna inermis and Cassia sieberiana followed with IVIs of 65.43 and 52.43, respectively (Table A2). At Bontioli Nature Reserve, the highest IVI was recorded for Mitragyna inermis, which was 98.59 (Table A2). Vitellaria paradoxa and Combretum fragrans followed with 43.55 and 35.75 , respectively (Table A2).

The highest FIV in Nazinga Game Ranch was recorded for Combretaceae, 109.25 (Table A3). It was followed by Fabaceae-Caesalpiniaceae, 56.50, and Rubiaceae, 48.12, respectively (Table A3). For Bontioli Nature Reserve, the highest FIV was also recorded for Combretaceae, 99.91 (Table A3). Rubiaceae and Fabaceae-Mimosoideae followed with 78.84 and 27.68, respectively (Table A3).

\section{Discussion}

\subsection{DBH and DBH Class Distribution}

The result for this study for mean $D B H$ for gallery forests was not consistent with [31] who reported mean $D B H$ of $15 \pm 3.84 \mathrm{~cm}$. This difference could be attributed to their low sampling intensity. Similarly, the result of this study was also higher than what was reported by [41], which reported a mean $D B H$ of $15.3 \pm 3.9 \mathrm{~cm}$ for the unprotected site Yale, in southern Burkina Faso. The difference could be due to higher $D B H$ s for gallery forests in this study. The $D B H$ classes' distribution, representing a horizontal structure, showed a reverse J-shape for both the sites in this study. The reverse J-shape is typical for tropical and sub-tropical forests [42]. The reverse J-shape is also an indication of good regeneration of the woody vegetation community [43]. The highest number of trees was recorded in the $D B H$ classes of $5 \mathrm{~cm}$ in our study for both the sites. The density decreased with increasing $D B H$ classes. Savadogo, P. [25] also emphasized that with increasing DBH the density decreases.

\subsection{Stem Densities, Tree Heights, and BA}

Savadogo, P., et al. [31] reported gallery forests as having the highest mean stem density, which is contrary to the result of this study. Savadogo, P. [25] reported a mean density of 331 tree $^{-h^{-1}}$ for the Bontioli Nature Reserve, which is close to the mean density for the Bontioli Nature Reserve for 
this study. The result for this study for overall mean density is close to [41] for their mean density of $703 \pm 49$ trees $\cdot \mathrm{ha}^{-1}$.

The height measurements were consistent with other studies [25,31,43], however [25] emphasized that trees' heights are leveled down by anthropogenic pressures such as bushfires and wood cuttings. High values for mean BA for gallery forests were also confirmed [31,43].

\section{3. $A G B_{d r y}$ and Carbon Stocks}

This study revealed that mean $A G B_{\text {dry }}$ and carbon stocks for Nazinga Game Ranch and Bontioli Nature Reserve were not significantly different. This can be attributed to the mean $D B H$ s and mean heights which were also not significantly different between the two sites. Overall, the similarity between the two sites, as shown statistically, could be attributed to the similar environmental conditions. To the authors' knowledge, there are no $A G B_{\text {dry }}$ and carbon stock estimates available for these two sites. Previous estimates would have helped in comparison with results of this study. Lewis, S.L. et al. [44] also emphasized that only very few carbon stock estimates based on field inventories are available for West Africa. Estimates for carbon stocks have been provided by [8] for all of Burkina Faso, but this data was not comparable with this study because of the national level focus on different land uses categorized according to [45].

In this study, the highest overall mean carbon stock was recorded for gallery forests. The mean carbon stock of gallery forests was also significantly different from other vegetation types. This significant difference could be attributed to their mean $D B H$, which was also the highest amongst the vegetation types. The gallery forests were mainly comprised of Mitragyna inermis. This species was the second most abundant species amongst all the species collectively from both sites. Mitragyna inermis was mainly found in clumps and was mostly comprised of multi-stem trees. It can be assumed that the calculation of the DBH of Mitragyna inermis, through the Equation (1) used in this study, may have resulted in an overestimation for $D B H$ s for gallery forests and hence in the overall mean carbon stock estimation. There is no statistical difference among the remaining vegetation types: the mean $D B H$ of woodland savannas was not significantly different from the tree and shrub savannas either. However, the density of woodland savannas was higher than the other two.

Sawadogo, L., et al. [46] reported $A G B_{\text {dry, }}$ through destructive sampling, for Anogeissus leiocarpa, Combretum glutinosum, Detarium microcarpum, Entada africana, and Piliostigma thonningii as $320.95 \mathrm{~kg}$, $42.26 \mathrm{~kg}, 61.74 \mathrm{~kg}, 32.16 \mathrm{~kg}$, and $29.42 \mathrm{~kg}$, respectively, for the sites of Laba and Tiogo State Forests, located in transition from the north to south Sudanian zone in Burkina Faso. The estimates for $A G B_{\text {dry }}$ for this study were only consistent with [46] for Entada africana (30.94 kg) in the Bontioli Nature Reserve. Estimates were not consistent in the case of Anogeissus leiocarpa (168.34 kg and $508.64 \mathrm{~kg}$ for Nazinga Game Ranch and Bontioli Nature Reserve, respectively); for Combretum glutinosum (19.03 kg) for Bontioli Nature Reserve; for Detarium microcarpum (37.87 kg) for Nazinga Game Ranch; and for Piliostigma thonningii (14.21 kg and $11.61 \mathrm{~kg}$ for Nazinga Game Ranch and Bontioli Nature Reserve, respectively). Inconsistencies between estimates of $A G B_{\text {dry }}$ between two studies could be because of the variability of basic wood density in the individuals of the same species for different geographical locations and ages [47]. Karlson, M., et al. [48] reported $A G B_{\text {dry }}$ of $15.96 \mathrm{Mg} \cdot \mathrm{ha}^{-1}$ for Saponé, central Burkina Faso. They included open woodlands, agroforestry parklands, small scale tree plantations, and dense forest patches in their study. These stands are often characterized by trees of bigger sizes, which could be the reason why higher $A G B_{\text {dry }}$ estimates were recorded for them in comparison to this study. The result for this study for mean carbon stock for both sites collectively was higher than [49] who reported $1.10 \pm 0.32 \mathrm{Mg} \cdot \mathrm{C} \cdot \mathrm{ha}^{-1}$ for natural vegetation with high degradation for Bale province, south Sudanian zone, western Burkina Faso-where they used the same generalized allometric equation for estimation of $A G B_{\text {dry }}$ given by [34], Equation (2), which was used for this study. 


\subsection{Floristics}

The results of this study for Combretaceae and Rubiaceae as the most abundant families for both sites collectively is consistent with $[25,31,41,50]$. The most common families in this study were Combretaceae, Rubiaceae, and Fabaceae-Caesalpiniaceae, which portrays a typical taxonomic pattern of savanna-woodland mosaics in Africa and for the northern Sudanian zone in Burkina Faso [51].

Savadogo, P., et al. [31] reported the highest IVI of 214.50 for Mitragyna inermis, which is also consistent with the result for Nazinga Game Ranch for this study. The high IVI for Mitragyna inermis in this study for Nazinga Game Ranch may also suggest that gallery forests are less affected by human disturbances [50,52]. Karlson, M., et al. [48] reported 37 species for their study site at Saponé, central Burkina Faso, which is close to 29 species collectively for both sites in this study. Species such as Detarium microcarpum and Lannea microcarpa were amongst the rarest recorded for both sites collectively in this study. This could be attributed to the preferences of local inhabitants at both sites for these two species for the associated multiple benefits which can be derived from them [25]. The highest number of 140 individuals was recorded for Anogeissus leiocarpa for Nazinga Game Ranch against a contrasting 12 trees for Bontioli Nature Reserve. This drastic difference could be due to the proximity of this species to the settlements in Bontioli Nature Reserve. Anogeissus leiocarpa is known for its medicinal qualities and hence could be the subject of prodigious cutting in Bontioli Nature Reserve [53].

\section{Conclusions}

The highest mean $A G B_{\mathrm{dry}}$ and highest mean carbon stock were recorded for Bontioli Nature Reserve, however, statistically there was no significant difference recorded between the two investigated sites for these two variables. Significant difference was recorded between the vegetation types collectively for both sites where the highest mean $A G B_{\text {dry }}$ and the highest mean carbon stock were recorded for gallery forests. The highest FIV was recorded for Combretaceae for both of the sites. The highest IVIs were recorded for Anogeissus leiocarpa and Mitragyna inermis for the sites of Nazinga Game Ranch and Bontioli Nature Reserve, respectively.

This study contributes in addressing the knowledge gap on carbon stocks of protected savannas in West Africa. To the authors' knowledge, it was a first attempt to estimate the $A G B_{\text {dry }}$ and carbon stocks of different vegetation types at the two protected areas of Nazinga Game Ranch and Bontioli Nature Reserve. The results of this study can therefore serve as a benchmark for future studies and baselines for future possible payment for environmental initiatives and REDD+ programmes, if initiated for these areas. This study also provides insights that can be useful for areas with similar environmental settings.

It is suggested that land use and land cover change analysis and carbon inventories over different time periods should be conducted at these two sites in the future, as they can also provide a good picture of deforestation and degradation at these two sites. [28], for instance, have reported losses of vegetation cover over the past 29 years as a result of agriculture expansion at Bontioli Nature Reserve through land use and land cover change analysis using remote sensing and questionnaire surveys combined. A similar study for Nazinga Game Ranch, where there are also reports of high dependency of local communities on the vegetation [22], would also be helpful for the identification of drivers responsible for deforestation and degradation.

Acknowledgments: The field visit for this study was possible because of the postgraduate scholarship by the DAAD (German Academic Exchange Service). The logistic support was provided by the West African Science Service Centre on Climate Change and Adapted Land Use (WASCAL). The research was conducted as part of the WASCAL Project, funded by the German Federal Ministry of Education and Research (BMBF). We are thankful to Kangbéni Dimobe for identification of plant species. The authors are also thankful to the research assistants Christoph Höpel and Herman Hien for their support during the data collection. Last but not least, the authors are also grateful to Kangbéni Dimobe for the GIS maps with the location of sampling plots and for his generous help in locating these plots during the field visit. All authors are also grateful to the editors and two anonymous reviewers; their valuable comments significantly increased the quality of the manuscript. 
Author Contributions: Mohammad Qasim conducted the field work and contributed to the analysis of the data as well as in writing the first draft and revising the manuscript. Stefan Porembski co-developed the study design, supervised the floristic data analysis and contributed in revising the manuscript. Dietmar Sattler developed and supervised the biomass data analysis and contributed to writing the first draft and revising the manuscript. Katharina Stein co-developed the study design, supervised the field work on site and contributed in revising the manuscript. Adjima Thiombiano provided floristic data and contributed to the overall literature review and in revising the manuscript. Andre Lindner developed the study design and contributed in writing the first draft and revising the manuscript.

Conflicts of Interest: The authors declare no conflict of interest.

\section{Appendix A}

Table A1. Species represents the tree species at both sites of Nazinga Game Ranch and Bontioli Nature Reserve collectively. $N=$ number of trees for each species. Relative abundance (\%) (percentage of tree species individuals relative to the total number of trees). Wood density represents the published values of wood densities at species and generic levels for all the trees at both sites.

\begin{tabular}{|c|c|c|c|c|c|}
\hline \multirow{2}{*}{ Species } & \multirow{2}{*}{$N$} & \multirow{2}{*}{$\begin{array}{c}\text { Relative } \\
\text { Abundance (\%) }\end{array}$} & \multicolumn{2}{|c|}{ Wood Density $\left(\mathrm{g} \cdot \mathrm{cm}^{-3}\right)$} & \multirow{2}{*}{ References } \\
\hline & & & Species Level & Generic Level & \\
\hline $\begin{array}{c}\text { Acacia sieberiana DC. var. } \\
\text { villosa A. Chev. }\end{array}$ & 2 & 0.36 & 0.65 & & [54] \\
\hline Afzelia africana $\mathrm{Sm}$. & 1 & 0.18 & 0.71 & & [55] \\
\hline Anogeissus leiocarpa (DC.) Guill. \& Perr. & 152 & 28.04 & 0.73 & & [55] \\
\hline Bridelia scleroneura Müll. Arg. & 3 & 0.55 & & 0.81 & [56] \\
\hline Cassia sieberiana DC. & 16 & 2.95 & 0.72 & & [57] \\
\hline Combretum adenogonium Steud. ex A. Rich. & 13 & 2.39 & 0.64 & & [58] \\
\hline Combretum collinum Fresen. & 8 & 1.47 & 0.79 & & [54] \\
\hline Combretum fragrans F.Hoffm. & 37 & 6.82 & 0.64 & & [58] \\
\hline Combretum glutinosum Perr. ex DC. & 2 & 0.36 & 0.90 & & [59] \\
\hline Daniellia oliveri (Rolfe) Hutch. \& Dalz. & 13 & 2.39 & 0.40 & & [60] \\
\hline Detarium microcarpum Guill. \& Perr. & 4 & 0.73 & 0.78 & & [61] \\
\hline Diospyros mespiliformis Hochst. ex A. DC. & 1 & 0.18 & & 0.72 & [57] \\
\hline Entada africana Guill. \& Perr. & 7 & 1.29 & 0.53 & & [57] \\
\hline Gardenia erubescens Stapf \& Hutch. & 1 & 0.18 & 0.64 & & {$[54]$} \\
\hline Gardenia ternifolia Schum. \& Thonn. & 3 & 0.55 & 0.81 & & [56] \\
\hline Lannea microcarpa Engl. \& K. Krause & 1 & 0.18 & 0.51 & & [57] \\
\hline Maytenus senegalensis (Lam.) Exell & 2 & 0.36 & & 0.71 & [62] \\
\hline Mitragyna inermis (Willd.) O. Ktze. & 70 & 12.91 & & 0.56 & [62] \\
\hline Parkia biglobosa (Jacq.) R. Br. ex G. Don f. & 17 & 3.13 & 0.61 & & [63] \\
\hline Pericopsis laxiflora (Benth. ex Bak.) van Meeuwen & 1 & 0.18 & & 0.93 & {$[64]$} \\
\hline Piliostigma thonningii (Schum.) Milne-Redhead & 9 & 1.66 & 0.61 & & [57] \\
\hline Pseudocedrela kotschyi (Schweinf.) Harms & 7 & 1.29 & 0.62 & & [65] \\
\hline Pterocarpus erinaceus Poir. & 4 & 0.73 & 0.62 & & [57] \\
\hline Saba senegalensis (A. DC.) Pichon & 6 & 1.10 & & 0.62 & [57] \\
\hline Stereospermum kunthianum Cham. & 3 & 0.55 & 0.60 & & [58] \\
\hline Terminalia laxiflora Engl. \& Diels & 65 & 11.99 & & 0.71 & [62] \\
\hline Terminalia macroptera Guill. \& Perr. & 23 & 4.24 & & 0.71 & [62] \\
\hline Vitellaria paradoxa C.F. Gaertn. & 67 & 12.36 & 0.72 & & [66] \\
\hline Ximenia americana $\mathrm{L}$. & 4 & 0.73 & 0.95 & & [59] \\
\hline
\end{tabular}

UNFCCC $=$ United Nations Framework Convention on Climate Change. 
Table A2. Importance Value Index (IVI) of tree species at Nazinga Game Ranch and Bontioli Nature Reserve. $R f(\%)$ is the relative frequency of tree species, $R D e(\%)$ is the relative density of trees species, and $R D o(\%)$ is the relative basal area of the tree species.

\begin{tabular}{|c|c|c|c|c|}
\hline \multicolumn{5}{|c|}{ Nazinga Game Ranch } \\
\hline Species & $R f(\%)$ & $R D e(\%)$ & $R D o(\%)$ & IVI \\
\hline Afzelia africana Sm. & 5 & 0.38 & 0.67 & 6.06 \\
\hline Anogeissus leiocarpa (DC.) Guill. \& Perr. & 35 & 53.84 & 26.72 & 115.56 \\
\hline Cassia sieberiana DC. & 30 & 6.15 & 16.28 & 52.43 \\
\hline Detarium microcarpum Guill. \& Perr. & 10 & 1.53 & 0.25 & 11.79 \\
\hline Diospyros mespiliformis Hochst. ex A. DC. & 5 & 0.38 & 0.04 & 5.43 \\
\hline Maytenus senegalensis (Lam.) Exell & 10 & 0.76 & 0.08 & 10.85 \\
\hline Mitragyna inermis (Willd.) O. Ktze. & 25 & 8.84 & 31.58 & 65.43 \\
\hline Parkia biglobosa (Jacq.) R. Br. ex G. Don f. & 5 & 0.38 & 5.13 & 10.51 \\
\hline Piliostigma thonningii (Schum.) Milne-Redhead & 5 & 0.38 & 0.06 & 5.44 \\
\hline Saba senegalensis (A. DC.) Pichon & 15 & 2.30 & 14.17 & 31.48 \\
\hline Stereospermum kunthianum Cham. & 5 & 0.38 & 0.03 & 5.42 \\
\hline Terminalia laxiflora Engl. \& Diels & 25 & 11.15 & 2.14 & 38.29 \\
\hline Vitellaria paradoxa C.F. Gaertn. & 25 & 13.46 & 2.78 & 41.25 \\
\hline \multicolumn{5}{|c|}{ Bontioli Nature Reserve } \\
\hline Species & $R f(\%)$ & $R D e(\%)$ & RDo $(\%)$ & IVI \\
\hline Acacia sieberiana DC. var. villosa A. Chev. & 5 & 0.70 & 0.16 & 5.87 \\
\hline Anogeissus leiocarpa (DC.) Guill. \& Perr. & 15 & 4.25 & 6.12 & 25.38 \\
\hline Bridelia scleroneura Müll. Arg. & 5 & 1.06 & 0.51 & 6.57 \\
\hline Combretum adenogonium Steud. ex A. Rich. & 15 & 4.60 & 2.00 & 21.61 \\
\hline Combretum collinum Fresen. & 5 & 2.83 & 0.50 & 8.33 \\
\hline Combretum fragrans F.Hoffm. & 15 & 13.12 & 7.62 & 35.75 \\
\hline Combretum glutinosum Perr. ex DC. & 10 & 0.70 & 0.10 & 10.81 \\
\hline Daniellia oliveri (Rolfe) Hutch. \& Dalz. & 15 & 4.60 & 9.63 & 29.24 \\
\hline Entada africana Guill. \& Perr. & 10 & 2.48 & 0.51 & 12.99 \\
\hline Gardenia erubescens Stapf \& Hutch. & 5 & 0.35 & 0.06 & 5.41 \\
\hline Gardenia ternifolia Schum. \& Thonn. & 10 & 1.06 & 0.72 & 11.78 \\
\hline Lannea microcarpa Engl. \& K. Krause & 5 & 0.35 & 0.26 & 5.61 \\
\hline Mitragyna inermis (Willd.) O. Ktze. & 35 & 16.66 & 46.93 & 98.59 \\
\hline Parkia biglobosa (Jacq.) R. Br. ex G. Don f. & 10 & 5.67 & 5.09 & 20.77 \\
\hline Pericopsis laxiflora (Benth. ex Bak.) van Meeuwen & 5 & 0.35 & 0.18 & 5.53 \\
\hline Piliostigma thonningii (Schum.) Milne-Redhead & 20 & 2.83 & 0.31 & 23.15 \\
\hline Pseudocedrela kotschyi (Schweinf.) Harms & 10 & 2.48 & 1.59 & 14.07 \\
\hline Pterocarpus erinaceus Poir. & 5 & 1.41 & 3.39 & 9.81 \\
\hline Stereospermum kunthianum Cham. & 5 & 0.70 & 0.05 & 5.76 \\
\hline Terminalia laxiflora Engl. \& Diels & 20 & 12.76 & 2.92 & 35.69 \\
\hline Terminalia macroptera Guill. \& Perr. & 5 & 8.15 & 3.73 & 16.89 \\
\hline Vitellaria paradoxa C.F. Gaertn. & 25 & 11.34 & 7.20 & 43.55 \\
\hline Ximenia americana L. & 15 & 1.41 & 0.30 & 16.72 \\
\hline
\end{tabular}

Table A3. FIV of Nazinga Game Ranch and Bontioli Nature Reserve. $R D i(\%)$ is the relative diversity of the plant family, $R D e(\%)$ is the relative density of the plant family and $R D o(\%)$ is the relative basal area of the plant family.

\begin{tabular}{|c|c|c|c|c|}
\hline \multicolumn{5}{|c|}{ Nazinga Game Ranch } \\
\hline Family & $R D i(\%)$ & $R D e(\%)$ & $R D o(\%)$ & FIV \\
\hline Apocynaceae & 7.69 & 2.30 & 14.17 & 24.17 \\
\hline Bignoniaceae & 7.69 & 0.38 & 0.03 & 8.11 \\
\hline Fabaceae-Caesalpiniaceae & 30.76 & 8.46 & 17.27 & 56.50 \\
\hline Celastraceae & 7.69 & 0.76 & 0.08 & 8.54 \\
\hline Combretaceae & 15.38 & 65 & 28.86 & 109.25 \\
\hline Ebenaceae & 7.69 & 0.38 & 0.04 & 8.12 \\
\hline Fabaceae-Mimosoideae & 7.69 & 0.38 & 5.13 & 13.21 \\
\hline Rubiaceae & 7.69 & 8.84 & 31.58 & 48.12 \\
\hline Sapotaceae & 7.69 & 13.46 & 2.78 & 23.94 \\
\hline \multicolumn{5}{|c|}{ Bontioli Nature Reserve } \\
\hline Family & $R D i(\%)$ & $R D e(\%)$ & $R D o(\%)$ & FIV \\
\hline Anacardiaceae & 4.34 & 0.35 & 0.26 & 4.96 \\
\hline Bignoniaceae & 4.34 & 0.70 & 0.05 & 5.11 \\
\hline Fabaceae-Caesalpiniaceae & 8.69 & 7.44 & 9.95 & 26.09 \\
\hline Combretaceae & 30.43 & 46.45 & 23.02 & 99.91 \\
\hline Euphorbiaceae & 4.34 & 1.06 & 0.51 & 5.92 \\
\hline Fabaceae-Papilionioideae & 8.69 & 1.77 & 3.58 & 14.04 \\
\hline Meliaceae & 4.34 & 2.48 & 1.59 & 8.42 \\
\hline Fabaceae-Mimosoideae & 13.04 & 8.86 & 5.77 & 27.68 \\
\hline Olacaceae & 4.34 & 1.41 & 0.30 & 6.07 \\
\hline Rubiaceae & 13.04 & 18.08 & 47.72 & 78.84 \\
\hline Sapotaceae & 4.34 & 11.34 & 7.20 & 22.89 \\
\hline
\end{tabular}




\section{References}

1. Sop, T.K.; Oldeland, J.; Schmiedel, U.; Ouedraogo, I.; Thiombiano, A. Population structure of three woody species in four ethnic domains of the sub-sahel of Burkina Faso. Land Degrad. Dev. 2011, 22, 519-529. [CrossRef]

2. Arevalo, J. Improving woodfuel governance in Burkina Faso: The experts' assessment. Renew. Sustain. Energy Rev. 2016, 57, 1398-1408. [CrossRef]

3. Luck, G.W. A review of the relationships between human population density and biodiversity. Biol. Rev. 2007, 82, 607-645. [CrossRef] [PubMed]

4. Jurisch, K.; Hahn, K.; Wittig, R.; Bernhardt-Römermann, M. Population Structure of Woody Plants in Relation to Land Use in a Semi-arid Savanna, West Africa. Biotropica 2012, 44, 744-751. [CrossRef]

5. Bayen, P.; Lykke, A.M.; Thiombiano, A. Success of three soil restoration techniques on seedling survival and growth of three plant species in the Sahel of Burkina Faso (West Africa). J. For. Res. 2016, 27, 313-320. [CrossRef]

6. Schmidt, M.; Traoré, S.; Ouédraogo, A.; Mbayngone, E.; Ouédraogo, O.; Zizka, A.; Kirchmair, I.; Kaboré, E.; Tindano, E.; Thiombiano, A.; et al. Geographical patterns of woody plants' functional traits in Burkina Faso. Candollea 2013, 68, 197-202. [CrossRef]

7. Ky-Dembele, C.; Tigabu, M.; Bayala, J.; Odén, P.C. Inter- and intra-provenances variations in seed size and seedling characteristics of Khaya senegalensis A. Agrofor. Syst. 2014, 88, 311-320. [CrossRef]

8. Fischer, C.; Kleinn, C.; Fehrmann, L.; Fuchs, H.; Panferov, O. A national level forest resource assessment for Burkina Faso - A field based forest inventory in a semiarid environment combining small sample size with large observation plots. For. Ecol. Manag. 2011, 262, 1532-1540. [CrossRef]

9. Ministry of Environment and Sustainable Development. Readiness Preparation Plan For Redd; Ministry of the Environment and Sustainable Development: Ouagadougou, Burkina Faso, 2012.

10. Food and Agriculture Organization (FAO). Global Forest Resources Assessment 2015; FAO: Rome, Italy, 2015 ; p. 253.

11. Collins, L.; Penman, T.; Ximenes, F.A.; Binns, D.; York, A.; Bradstock, R. Impacts of frequent burning on live tree carbon biomass and demography in post-harvest regrowth forest. Forests 2014, 5, 802-821. [CrossRef]

12. Koffi, C.K.; Djoudi, H.; Gautier, D. Landscape diversity and associated coping strategies during food shortage periods: Evidence from the Sudano-Sahelian region of Burkina Faso. Reg. Environ. Chang. 2016, 1-12. [CrossRef]

13. Bluffstone, R.; Robinson, E.; Guthiga, P. REDD+ and community-controlled forests in low-income countries: Any hope for a linkage? Ecol. Econ. 2013, 87, 43-52. [CrossRef]

14. Ngo, K.M.; Turner, B.L.; Muller-Landau, H.C.; Davies, S.J.; Larjavaara, M.; Hassan, N.F.; Lum, S. Carbon stocks in primary and secondary tropical forests in Singapore. For. Ecol. Manag. 2013, 296, 81-89. [CrossRef]

15. Stern, N. Climate. Stern Review: The Economics of Climate Change. N. Engl. J. Public Policy 2007, 21, 4.

16. Birdsey, R.; Pan, Y.; Houghton, R. Sustainable landscapes in a world of change: Tropical forests, land use and implementation of REDD+: Part II. Carbon Manag. 2013, 4, 567-569. [CrossRef]

17. Field, C.B.; Barros, V.R.; Dokken, D.J.; Mach, K.J.; Mastrandrea, M.D.; Bilir, T.E.; Chatterjee, M.; Ebi, K.L.; Estrada, Y.O.; Genova, R.C.; et al. IPCC Climate Change 2014: Impacts, Adaptation, and Vulnerability. Part A: Global and Sectoral Aspects. Contribution of Working Group II to the Fifth Assessment Report of the Intergovernmental Panel on Climate Change; Cambridge University Press: New York, NY, USA, 2014.

18. Woollen, E.; Ryan, C.M.; Williams, M. Carbon Stocks in an African Woodland Landscape: Spatial Distributions and Scales of Variation. Ecosystems 2012, 15, 804-818. [CrossRef]

19. Attua, E.M.; Pabi, O. Tree species composition, richness and diversity in the northern forest-savanna ecotone of Ghana. J. Appl. Biosci. 2013, 69, 5437-5448. [CrossRef]

20. Oliveira, P.J.C.; Asner, G.P.; Knapp, D.E.; Almeyda, A.; Galván-Gildemeister, R.; Keene, S.; Raybin, R.F.; Smith, R.C. Land-use allocation protects the Peruvian Amazon. Science 2007, 317, 1233-1236. [CrossRef] [PubMed]

21. Jenks, J.A.; Klaver, R.W.; Wicks, Z.W., III. Determinants of elephant distribution at Nazinga Game Ranch, Burkina Faso. Pachyderm 2007, 42, 70-80. 
22. Kristensen, M.; Balslev, H. Perceptions, use and availability of woody plants among the Gourounsi in Burkina Faso. Biodivers. Conserv. 2003, 12, 1715-1739. [CrossRef]

23. Hema, E.M.; Barnes, R.F.W.; Guenda, W. Distribution of savannah elephants (Loxodonta africana africana Blumenbach 1797) within Nazinga game ranch, Southern Burkina Faso. Afr. J. Ecol. 2011, 49, 141-149. [CrossRef]

24. Dekker, A. Carte de Paysage de la Région du Ranch de Gibier de Nazinga, Burkina Faso; PNUD/FAO, DP/BKF/82/008; Adefa: Buenos Aires, Argentina, 1985.

25. Tia, L. Modeling of Vegetation Dynamics and Its Contribution to the Water Balance in Semi-Arid Lands of West Africa; Rheinische Friedrich-Wilhelms-Universität Bonn: Bonn, Germany, 2007; p. 174.

26. Grote, R.; Lehmann, E.; Brümmer, C.; Brüggemann, N.; Szarzynski, J.; Kunstmann, H. Modelling and observation of biosphere-atmosphere interactions in natural savannah in Burkina Faso, West Africa. Phys. Chem. Earth 2009, 34, 251-260. [CrossRef]

27. Schmidt, M.; Mbayngone, E.; Bachmann, Y.; Hahn, K.; Zizka, G.; Thiombiano, A. The impact of land use on species composition and habitat structure in Sudanian savannas-A modelling study in protected areas and agricultural lands of southeastern Burkina Faso. Candollea 2016, 71, 265-274. [CrossRef]

28. Dimobe, K.; Ouédraogo, A.; Soma, S.; Goetze, D.; Porembski, S.; Thiombiano, A. Identification of driving factors of land degradation and deforestation in the Wildlife Reserve of Bontioli (Burkina Faso, West Africa). Glob. Ecol. Conserv. 2015, 4, 559-571. [CrossRef]

29. Fournier-Mary, A. Phenologie, Croissance et Production Vegetales Dans Quelques Savanes D’afrique de L'ouest. Variation Selon un Gradient de Secheresse. Available online: http://horizon.documentation.ird.fr/ exl-doc/pleins_textes/pleins_textes_2/etudes_theses/36403.pdf (accessed on 14 August 2016).

30. Kabore, E.; Sambare, O.; Ouedraogo, A.; Thiombiano, A. Diversité et structure des cordons ripicoles le long de la sirba (Nord-Est du Burkina Faso). Int. J. Biol. Chem. Sci. 2013, 7, 1929-1950. [CrossRef]

31. Savadogo, P.; Tigabu, M.; Sawadogo, L.; Odén, P.C. Woody species composition, structure and diversity of vegetation patches of a Sudanian savanna in Burkina Faso. Bois For. Trop. 2007, 294, 5-20.

32. Holdaway, R.J.; McNeill, S.J.; Mason, N.W.; Carswell, F.E. Propagating uncertainty in plot-based estimates of forest carbon stock and carbon stock change. Ecosystems 2014, 17, 627-640. [CrossRef]

33. Cienciala, E.; Centeio, A.; Blazek, P.; Soares, M.C.G.; Russ, R. Estimation of stem and tree level biomass models for Prosopis juliflora/pallida applicable to multi-stemmed tree species. Trees 2013, 27, 1061-1070. [CrossRef]

34. Chave, J.; Andalo, C.; Brown, S.; Cairns, M.A.; Chambers, J.Q.; Eamus, D.; Fölster, H.; Fromard, F.; Higuchi, N.; Kira, T.; et al. Tree allometry and improved estimation of carbon stocks and balance in tropical forests. Oecologia 2005, 145, 87-99. [CrossRef] [PubMed]

35. Chave, J.; Réjou-Méchain, M.; Búrquez, A.; Chidumayo, E.; Colgan, M.S.; Delitti, W.B.C.; Duque, A.; Eid, T.; Fearnside, P.M.; Goodman, R.C.; et al. Improved allometric models to estimate the aboveground biomass of tropical trees. Glob. Chang. Biol. 2014, 20, 3177-3190. [CrossRef] [PubMed]

36. Tran, D.B.; Dargusch, P.; Herbohn, J.; Moss, P. Interventions to better manage the carbon stocks in australian melaleuca forests. Land Use Policy 2013, 35, 417-420. [CrossRef]

37. Iles, K.; Wilson, L.J. A further neglected mean. Math. Teach. 1977, 70, 27-28.

38. Medawatte, A.W.; Amarasinghe, J.; Iqbal, M.C.; Ranwala, S.M. Restoration of a degraded dry forest using nurse trees at Dambulla, Sri Lanka. Conserv. Evid. 2014, 11, 16-19.

39. Mori, S.A.; Boom, B.M.; de Carvalino, A.M. Ecological importance of Myrtaceae in an eastern Brazilian wet forest. Biotropica 1983, 15, 68-70. [CrossRef]

40. R Core Team. R: A Language and Environment for Statistical Computing; R Foundation for Statistical Computing: Vienna, Austria, 2014.

41. Paré, S.; Tigabu, M.; Savadogo, P.; Odén, P.C.; Ouadba, J.M. Does designation of protected areas ensure conservation of tree diversity in the Sudanian dry forest of Burkina Faso? Afr. J. Ecol. 2010, 48, 347-360. [CrossRef]

42. Ribeiro, N.S.; Matos, C.N.; Moura, I.R.; Washington-Allen, R.A.; Ribeiro, A.I. Monitoring vegetation dynamics and carbon stock density in miombo woodlands. Carbon Balanc. Manag. 2013, 8, 11. [CrossRef] [PubMed]

43. Traoré, L.; Ouédraogo, A.; Thiombiano, A. To what extent do protected areas determine the conservation of native flora? A case study in the Sudanian zone of Burkina Faso. ISRN Bot. 2012, 2012. [CrossRef] 
44. Lewis, S.L.; Lloyd, J.; Sitch, S.; Mitchard, E.T.A.; Laurance, W.F. Changing Ecology of Tropical Forests: Evidence and Drivers. Annu. Rev. Ecol. Evol. Syst. 2009, 40, 529-549. [CrossRef]

45. Food and Agriculture Organization (FAO). Global Forest Resources Assessment 2010: Main Report; FAO: Rome, Italy, 2010; p. 340.

46. Sawadogo, L.; Savadogo, P.; Tiveau, D.; Dayamba, S.D.; Zida, D.; Nouvellet, Y.; Oden, P.C.; Guinko, S. Allometric prediction of above-ground biomass of eleven woody tree species in the Sudanian savanna-woodland of West Africa. J. For. Res. 2010, 21, 475-481. [CrossRef]

47. Fearnside, P.M. Wood density for estimating forest biomass in Brazilian Amazonia. For. Ecol. Manag. 1997, 90, 59-87. [CrossRef]

48. Karlson, M.; Ostwald, M.; Reese, H.; Sanou, J.; Tankoano, B.; Mattsson, E. Mapping tree canopy cover and aboveground biomass in Sudano-Sahelian woodlands using Landsat 8 and Random Forest. Remote Sens. 2015, 7, 10017-10041. [CrossRef]

49. Dayamba, S.D.; Djoudi, H.; Zida, M.; Sawadogo, L.; Verchot, L. Biodiversity and carbon stocks in different land use types in the Sudanian Zone of Burkina Faso, West Africa. Agric. Ecosyst. Environ. 2016, 216, 61-72. [CrossRef]

50. Dimobe, K.; Wala, K.; Dourma, M.; Kiki, M.; Woegan, Y.; Folega, F.; Batawila, K.; Akpagana, K. Disturbance and population structure of plant communities in the wildlife reserve of Oti-Mandouri in Togo (West Africa). Annu. Res. Rev. Biol. 2014, 4, 2501-2516.

51. Bognounou, F.; Thiombiano, A.; Savadogo, P.; Issaka Boussim, J.; Christer Oden, P.; Guinko, S. Woody vegetation structure and composition at four sites along a latitudinal gradient in Western Burkina Faso. Bois For. Trop. 2009, 22, 29-44.

52. Porembski, S. Phytodiversity and structure of the Comoé river gallery forest (NE Ivory Coast). In Life Forms and Dynamics in Tropical Forests; Borntraeger: Berlin, Germany, 2001; pp. 1-10.

53. Arbab, A.H. Review on Anogeissus leiocarpus a potent African traditional drug. Int. J. Res. Pharm. Chem. 2014, 4, 496-500.

54. The United Nations Framework Convention on Climate Change (UNFCCC). UNFCCC Local Data for Wood Densities: Reference No. 16 a; UNFCCC: Bonn, Germany, 1992.

55. Ogunwusi, A.A.; Onwualu, A.P.; Ogunsanwo, O.Y. Comparative Analysis of Wood Properties of Afzelia Africana and Anogeissus leiocarpus Growing in Nigeria. Chem. Mater. Res. 2013, 3, 8-13.

56. Agbontalor, E.A. Influence of specific gravity on wood species selection for agroforestry in some Local Government Areas of Oyo State, Nigeria. J. Agric. Res. 2008, 3, 134-139.

57. Nyg, R.; Elfving, B. Stem basic density and bark proportion of 45 woody species in young savanna coppice forests in Burkina Faso. Ann. For. Sci. 2000, 57, 143-153. [CrossRef]

58. Brazier, J.D.; Goldsmith, B.; Carter, D.T. The Indigenous Timbers of Zimbabwe. Zimbabwe Bulletin of Forestry Research No 9; JSTOR: Salisbury, Zimbabwe, 1983.

59. Von Maydell, H.J. Arbres et Arbustes du Sahel: Leurs Caracteristiques et Leurs Utilisations; Deutsche Gesellschaft fur Technische Zusammenarbeit (GTZ) GmbH: Eschborn, Germany, 1983.

60. Rijsdijk, J.F.; Laming, P.B. Physical and Related Properties of 145 Timbers: Information for Practice; Kluwer Academic Publishers: Dordrecht, The Netherlands, 1994.

61. Fontodji, J.K.; Tagba, M.S.; Akponikpe, P.B.I.; Adjonou, K.; Akossou, A.Y.J.; Akouehou, G.; Kokutse, A.D.; Nuto, Y.; Kokou, K. Diagnostic analysis of the techniques of carbonization inTogo (West Africa). Sci. J. Environ. Sci. 2013, 2, 106-117.

62. Brown, S. Estimating Biomass and Biomass Change of Tropical Forests: A Primer; FAO Forestry Paper; Food and Agriculture Organization of the United Nations: Rome, Italy, 1997; Volume 134.

63. Bolza, E.; Keating, W.G. African Timbers-The Properties, Uses and Characteristics of 700 Species; CSIRO: Melbourne, Australia, 1972.

64. Louppe, D.; Oteng-Amoako, A.; Brink, M. Prota 7 (1): Timbers/Bois d'oeuvre 1; PROTA: Wageningen, The Netherlands, 2008. 
65. Takahashi, A. Compilation of Data on the Mechanical Properties of Foreign Woods; Shimane University: Matsue, Japan, 1978.

66. Van der Vossen, H.A.M.; Mkamilo, G.S. Vegetable Oils of Tropical Africa, Conclusions and Recommendations Based on PROTA 14: "Vegetable Oils"; PROTA: Wageningen, The Netherlands, 2007.

(c) 2016 by the authors; licensee MDPI, Basel, Switzerland. This article is an open access article distributed under the terms and conditions of the Creative Commons Attribution (CC-BY) license (http://creativecommons.org/licenses/by/4.0/). 